Revision Article

\title{
Quality of life at work: Brazilian nursing literature review*
}

\author{
Qualidade de vida no trabalho: avaliação da produção cientifica na enfermagem brasileira
}

Calidad de vida en el trabajo: evaluación de la producción cientifica en la enfermería Brasileña

\section{Denise Rodrigues Costa Schmidt ${ }^{1}$, Rosana Aparecida Spadoti Dantas ${ }^{2}$, Maria Helena Palucci Marziale ${ }^{3}$}

\begin{abstract}
Objective: To analyze how Quality of Working Life (QWL) / Quality of Life at Work (QLW) has been studied, and assess the Brazilian nursing professionals' satisfaction. Methods: Articles were selected using the following databases: LILACS; CAPES; DEDALUS; UNICAMP; UNIFESP; and UNESP. The selected studies were analyzed based on some evaluation criteria used in studies about Quality of Life: concepts and domains, used instruments and investigated population. Results: Of the 47 studies found, 17 (36.1\%) met the established inclusion criteria. The term QWL/QLW was conceptualized in eight articles (47.0\%). Eleven papers (64.7\%) pointed out the analyzed domains. The QWL/QLW concept was more related to professional satisfaction, while the most approached domain was payment. Seven instruments were found, and the Index of Professional Satisfaction was the most used (23.5\%). Conclusion: Generally, there was no consensus among the researched authors regarding the QWL/QLW concept and the domains of the evaluated studies.
\end{abstract}

Keywords: Quality of life; Work; Job satisfaction; Scientific and technical publications

\section{RESUMO}

Objetivo: Analisar como tem sido estudada a Qualidade de Vida no Trabalho (QVT) e a satisfação profissional na enfermagem brasileira. Métodos: Para a seleção dos artigos utilizaram-se as seguintes bases de dados: LILACS; CAPES; DEDALUS; UNICAMP; UNIFESP e UNESP. Os estudos selecionados foram analisados empregando alguns critérios de avaliação utilizados em estudos sobre Qualidade de Vida: conceito e domínios, instrumentos utilizados e população investigada. Resultados: Dos 47 estudos encontrados, 17 (36,1\%) atenderam aos critérios de inclusão estabelecidos. O termo QVT foi conceituado em oito publicações $(47,0 \%$ e 11 (64,7\%) apontaram os domínios analisados. O conceito de QVT esteve mais relacionado à satisfação profissional, enquanto o domínio mais abordado foi a remuneração. Foram identificados sete instrumentos, sendo o Índice de Satisfação Profissional o mais usado (23,5\%). Conclusão: De modo geral não existiu consenso entre os autores das pesquisas analisadas quanto ao conceito de QVT e aos domínios do trabalho avaliados.

Descritores: Qualidade de vida; Trabalho; Satisfação no emprego; Publicações científicas e técnicas

\section{RESUMEN}

Objetivo: Analizar cómo ha sido estudiada la calidad de Vida en el Trabajo (CVT) y la satisfacción profesional en la enfermería brasileña. Métodos: Para la selección de los artículos se utilizaron las siguientes bases de datos: LILACS; CAPES; DEDALUS; UNICAMP; UNIFESP y UNESP. Los estudios seleccionados fueron analizados empleando algunos criterios de evaluación utilizados en estudios sobre Calidad de Vida: concepto y dominios, instrumentos utilizados y población investigada. Resultados: De los 47 estudios encontrados, 17 (36,1\%) atendieron a los criterios de inclusión establecidos. El término CVT fue conceptualizado en ocho publicaciones (47,0 \%) y 11 (64,7\%) apuntaron los dominios analizados. El concepto de CVT estuvo más relacionado a la satisfacción profesional y el dominio más abordado fue la remuneración. Fueron identificados siete instrumentos, siendo el Índice de Satisfacción Profesional el más usado (23,5\%). Conclusión: De modo general no existió consenso entre los autores de las investigaciones analizadas respecto al concepto de CVT y a los dominios del trabajo evaluados.

Descriptores: Calidad de vida; Trabajo; Satisfacción en el empleo; Publicaciones científicas y técnicas

1 Student of the Nursing Graduate Program at Escola de Enfermagem de Ribeirão Preto at Universidade de São Paulo - USP - Ribeirão Preto (SP), Brazil; Nurse at the Surgical Center of the Hospital Universitário de Londrina (PR), Brasil.

${ }^{2}$ PhD, Professor of the General and Specialized Nursing Department at Escola de Enfermagem de Ribeirão Preto at Universidade de São Paulo - USP Ribeirão Preto (SP), Brazil.

${ }^{3}$ Full Professor of the General and Specialized Nursing Department at Escola de Enfermagem de Ribeirão Preto at Universidade de São Paulo - USP Ribeirão Preto (SP), Brazill. 


\section{INTRODUCTION}

Quality of Life at Work (QLW) has been a concerning issue among professionals of different areas and is often evaluated as being the worker's satisfaction and wellbeing while performing his or her task ${ }^{(1)}$.

Several researchers have contributed with studies on individual's satisfaction at work. Such is the case of Elton Mayo, whose research was pioneering and of great relevance for the studies on human behavior, motivation and worker's quality of life $\mathrm{e}^{(1-2)}$.

Although studies on QLW have been conducted since the early $20^{\text {th }}$ century, there is no consensus about the real meaning of this term today. There is, however, an agreement among researchers in this specific field, which refer to it as a subjective and dynamic construct ${ }^{(3)}$.

Over the last years, QLW has been understood as the dynamic and comprehensive management of physical, technological, social, and psychological factors that affect culture and renew the organizational environment. Sometimes, it is considered regarding the effect it has on the worker's wellbeing as well as on the productivity of the company. Furthermore, it is sometimes associated with the intimate characteristic of the technologies introduced into the companies and their impact; and to the economic elements like salary, incentives, bonuses, or even to the factors connected to one's physical and mental health, safety, and, in general, to the worker's wellbeing ${ }^{(4)}$.

In addition to studying the QLW concept, another aspect that has been prioritized is the group of categories needed to assess QLW, and how they relate to each other ${ }^{(1)}$.

One of the first studies that addressed this aspect was performed in 1973. It proposed eight conceptual categories with the objective to supply a structure to assess QLW. Those were: adequate and fair compensation, safety and health conditions at work, immediate opportunity to use and develop one's capacity, further opportunity for continuous development and safety, social integration in the working organization, constitutionalism in the work organization, the work and the total space of life; and the social relevance of the worker's life ${ }^{(5)}$.

Among the authors who contributed for a better understanding about QLW issues are: Westley in 1979, Nadler and Lawler in 1983, Huse and Cummings and Hackman and Oldham in $1985^{(1)}$.

Satisfaction at work has become a key concept in QLW and nursing studies around the world ${ }^{(6-8)}$. Some studies have pointed out the importance measuring professional satisfaction, and suggested the association of satisfaction at work with a better quality of life ${ }^{(9)}$, smaller rates of work-related stress ${ }^{(10)}$, and smaller prevalence of Burnout Syndrome symptoms ${ }^{(11)}$.

Regarding QLW measurements among nursing professionals, several instruments have been created and used, and many of them bring professional satisfaction as the main definition of QLW.

Some instruments are classified as general, and are used to measure the professional satisfaction of worker's from different areas, such as the Job Satisfaction Survey ${ }^{(12)}$. There are specific instruments for measuring nurse's work satisfaction, such as the Index of Work Satisfaction ${ }^{(13)}$, Nurse Stress Index ${ }^{(14)}$, Muller/McCloskey Satisfaction ${ }^{(15)}$, Nurse Satisfaction Scale ${ }^{(16)}$, The Measure of Job Satisfaction ${ }^{(17)}$ and, more recently, Job Satisfaction in Nursing ${ }^{(8)}$.

The general scales, initially developed to measure satisfaction at work among industry and commerce workers, have also been used to assess the satisfaction at work among nurses. Furthermore, they are appropriate to compare the satisfaction of workers from different kinds of organizations ${ }^{(17)}$. The specific instruments, however, can better outline the components that are more important for the professional satisfaction of specific worker groups ${ }^{(15)}$.

The diversity of measure instruments based on distinct concepts about what QLW is can complicate the comparison of national results with the results from studies performed in other countries.

Hence, the purpose of the present study is to analyze how the term QLW and work satisfaction in Brazil has been studied, and find, in the pertinent literature, the proposed concepts and domains of QLW and professional satisfaction, the instruments used, and the worker populations studied in nursing.

\section{METHODS}

A review was conducted on the scientific literature published in Brazil about nursing professionals' QLW and satisfaction at work, published as abstracts in the scientific by summaries published in scientific event annals, articles, theses, and dissertations, published either in full-text or as summarized versions.

To identify the articles that would compose this study, we defined the follow inclusion criteria: studies that assessed the QLW or satisfaction at work of nurses or nursing professionals by means of specific or general instruments and through questionnaires with essay and multiple-choice questions, but that presented a quantitative approach; methodological studies about the development of the instruments of QLW or satisfaction at work for nurses or nursing professionals.

Studies were excluded if they evaluated the quality of life of nursing professionals and nursing faculty working at hospitals or basic health units. This criterion was adopted because the concept of quality of life, although much explored over the world, presents distinct characteristics regarding the concept of quality of life at 
work and professional satisfaction. Hence, our first interest was directed to QLW and satisfaction at work of nurses and nursing professionals, and comprehending their quality of life, or the quality of life, quality of life at work and professional satisfaction of nurse faculty members, which can be addressed in other studies.

No specific period was determined to begin the search, which means that a survey was conducted on all the production indexed in the American Latin Literature in Health Sciences (LILACS) ${ }^{(18)}$, available in the thesis databank of CAPES, Usp-DEDALUS ${ }^{(19)}$, UNICAMPACERVUS $^{(20)}$, UNIFESP(21), UNESP-ATHENA ${ }^{(22)}$. The search was concluded in December 2006, and the following keywords were used: qualidade de vida (quality of life), trabalho (work), satisfação no trabalho (job satisfaction) and enfermagem (nursing).

Data collection was performed by one of the authors, using an instrument that contained information on the study authors, database, type of publication, the method design (instrument used, domains of QLW or professional satisfaction, use of a global question to assess QLW), the sample profile, the studied intervention (study objective, adopted concept for QLW or satisfaction at work), study results and conclusions.

Of the 47 studies found, only 17 met the established inclusion criteria. Thus, those 17 studies were evaluated following the proposition of Gill; Feinstein ${ }^{(23)}$ about quality of life. These authors propose 10 criteria that evaluate issues related to the researchers (concept adopted, reason for choosing that evaluation instrument), as well as issues regarding the measurement instrument per se. The present study used seven of the 10 proposed criteria, modifying them for the focus on QLW.

Criteria used to evaluate the selected studies:

1. Does the researcher identify the concept that will be used for QLW?

2. Does the researcher present the QLW domains that will be measured?

3. Does the researcher justify the reasons for choosing that specific measurement instrument?

4. Does the researcher group the instrument domain results in a single QLW score?

5. Do the workers answer a global question about QLW?

6. Are the workers surveyed about the importance of QLW domains?

7. If affirmative, are these results are incorporated to the final result of the study?

\section{RESULTS}

A total 47 studies were found, which had nursing professionals' QLW or satisfaction at work as the main theme. Of the studies, 23 were excluded as they did not meet the inclusion criteria. Other seven studies were also disregarded: two did not present the type of instrument used, three were articles extracted from dissertations or theses (in this case, we chose to evaluate the studies in their more detailed forms) and two were not accessible, in either the full-text or summarized version.

Of the 17 studies selected, seven were scientific articles, all in-full texts; seven master degree theses, four of which were located as full-text and three doctorate dissertations, also full-text. Regarding the year of publication, the studies had been published since $1989^{(19)}$.

The 17 analyzed studies are presented below, according to the authors, year of publication, instruments used, number of items and of domains, and the presence of evaluation concerning work satisfaction and importance.

According to the seven criteria established for the study analysis, it was verified that there was no consensus among researchers on the QLW concept and domains to be addressed. This way, the employed QLW concept was sometimes associated to the satisfaction with some work components ${ }^{(32,35,38-39)}$, like payment, autonomy, professional status, and others; and at other times, it was associates to the worker's largest participation inside the organization $^{(26)}$, corroborating with other authors who state that Brazilian studies adopt the QLW thematic under distinct focuses ${ }^{(36,41)}$.

Four studies used the term QLW, three of which presented the definition that would be used in the study ${ }^{(26,36,39)}$. The term satisfaction at work was employed in 13 studies, but only five $e^{(27,30,32,35,38)}$ presented the applied concept. It was observed that, in the full-text dissertations and theses ${ }^{(26-27,32,35,36,38-39)}$, the authors presented the adopted concepts. The same did not occur in the articles, in which most authors were not concerned with presenting the definition that would be used in the study. The authors of the abstracts ${ }^{(25,31,33)}$ did not present the definition of the term used in their studies. However, this aspect may be related to the abstract size requirements for publication.

QLW domains were described in 11 studies $^{(24,26-29,32,35-}$ 36,38-40). The number of domains in the instruments ranged from 6 to 13, and the most often addressed were: payment, interaction, professional status, work requirements or goals, autonomy, organizational policy or rules, and opportunity for development.

With regard to the evaluation instruments, seven distinct instruments were found, of which the Index of Professional Satisfaction was used in four studies ${ }^{(32,35,38-}$ 39) and the Work Satisfaction Measurement Questionnaire in two $^{(27,40)}$. Six authors ${ }^{(25,30-31,33-34,37)}$ developed questionnaires with essay and multiple-choice questions about the addressed issue.

The elaboration of a specific instrument to evaluate nurses' QLW was proposed in two studies ${ }^{(29,36)}$ and the 
Chart 1 - Studies about QLW and/or professional satisfaction by author, year of publication, instruments used, the number of instrument items, number of domains, satisfaction and importance evaluation

\begin{tabular}{|c|c|c|c|c|c|}
\hline $\begin{array}{c}\text { Author/ year of } \\
\text { publication }\end{array}$ & Instrument & $\begin{array}{l}\text { Number of } \\
\text { items }\end{array}$ & $\begin{array}{l}\text { Number of } \\
\text { domains }\end{array}$ & $\begin{array}{c}\text { Satisfaction } \\
\text { Measurement }\end{array}$ & $\begin{array}{c}\text { Importance } \\
\text { Measurement }\end{array}$ \\
\hline Cassiani (1989)(24) & $\begin{array}{l}\text { Satisfaction } \\
\text { instrument }\end{array}$ & $\begin{array}{l}16(\text { Part 1) } \\
13(\text { Part 2) }\end{array}$ & 12 & Yes & Yes \\
\hline Jacomo $(1991)^{(25)}$ & Satisfaction form & None & Does not apply & Yes & Does not state \\
\hline Vieira (1993)(26) & $\begin{array}{c}\text { QLW Instrument } \\
\text { (Walton' categories) }\end{array}$ & 150 & 8 & Yes & Yes \\
\hline Del Cura (1994)(27) & $\begin{array}{c}\text { Work Satisfaction } \\
\text { measurement } \\
\text { questionnaire }\end{array}$ & 80 & 7 & Yes & No \\
\hline $\begin{array}{c}\text { Sawada; Galvão } \\
(1995)^{(28)}\end{array}$ & $\begin{array}{l}\text { Work Needs and } \\
\text { Satisfaction Scale }\end{array}$ & 23 & 12 & Yes & No \\
\hline $\begin{array}{l}\text { Santos; Rodrigues } \\
\text { Filho }(1995)^{(29)}\end{array}$ & $\begin{array}{l}\text { Nurse Satisfaction } \\
\text { Instrument }\end{array}$ & 18 & 6 & Yes & No \\
\hline $\begin{array}{c}\text { Antunes; } \\
\text { Santana }(1996)^{(30)} \\
\end{array}$ & $\begin{array}{c}\text { Questionnaire with } \\
\text { essay questions }\end{array}$ & None & Does not apply & Yes & No \\
\hline Dias (1999)(31) & $\begin{array}{l}\text { Questionnaire with } \\
\text { essay and multiple- } \\
\text { choice questions }\end{array}$ & None & Does not apply & Yes & Does not state \\
\hline Lino $(1999)^{(32)}$ & $\begin{array}{c}\text { Professional } \\
\text { Satisfaction Index }\end{array}$ & $\begin{array}{l}15 \text { (Part A) } \\
44(\text { Part B) }\end{array}$ & 6 & Yes & Yes \\
\hline Venâncio (2000)(33) & $\begin{array}{c}\text { Questionnaire with } \\
\text { essay questions - } \\
\text { QLW/stressors }\end{array}$ & None & Does not apply & No & No \\
\hline $\begin{array}{l}\text { West; Lisboa } \\
(2001)^{(34)}\end{array}$ & $\begin{array}{l}\text { Questionnaire with } \\
\text { multiple-choice } \\
\text { questions }\end{array}$ & 9 & Does not apply & Yes & No \\
\hline Matsuda (2002)(35) & $\begin{array}{c}\text { Professional } \\
\text { Satisfaction Index }\end{array}$ & $\begin{array}{l}15(\text { Part A) } \\
44(\text { Part B) }\end{array}$ & 6 & Yes & No \\
\hline Carandina $(2003)^{(36)}$ & $\begin{array}{c}\text { Nurse QLW } \\
\text { Measure instrument }\end{array}$ & 65 & 13 & Yes & Yes \\
\hline $\begin{array}{l}\text { Meirelles; Zeitoune } \\
\qquad(2003)^{(37)}\end{array}$ & $\begin{array}{c}\text { Questionnaire with } \\
\text { opened and closed } \\
\text { questions }\end{array}$ & None & Does not apply & Yes & No \\
\hline Lino $(2004)^{(38)}$ & $\begin{array}{c}\text { Professional } \\
\text { Satisfaction Index }\end{array}$ & $\begin{array}{l}15(\text { Part A) } \\
44(\text { Part B) }\end{array}$ & 6 & Yes & Yes \\
\hline Schmidt $(2004) *(39)$ & $\begin{array}{c}\text { Index of } \\
\text { Professional } \\
\text { Satisfaction (IPS) }\end{array}$ & 44 (Parte B) & 6 & Yes & No \\
\hline $\begin{array}{l}\text { Ferreira; Possari; } \\
\text { Moderno }(2006)^{(40)}\end{array}$ & $\begin{array}{l}\text { Work Satisfaction } \\
\text { measurement } \\
\text { questionnaire }\end{array}$ & 80 & 7 & Yes & Yes \\
\hline
\end{tabular}

* This author used only Part B of the instrument that evaluates professional satisfaction

cross-cultural adaptation of instruments to measure professional satisfaction was theme of another investigation ${ }^{(32)}$.

The major problem detected in the reviewed studies, with regard to the instruments, concerned the validation of the results. Some authors presented only the determination of content validity ${ }^{(24)}$, internal consistency $^{(26)}$, semantic analysis ${ }^{(27)}$, or factorial analysis ${ }^{(29)}$ of the used instruments.

Another important way to evaluate QLW studies is the explanation for choosing one specific measurement instrument. This was presented in six studies ${ }^{(27-28,32,36,38-39)}$. The presented explanations referred to the psychometrical properties of the instruments, the use in other studies, the number of items and, yet, to the lack of other specific measure for nurses working in hospitals.

In six studies ${ }^{(24,26,32,35-36,38)}$ the workers were asked about the importance related to work or career aspects by means of several questions. In two other studies ${ }^{(27,40)}$, the authors used an instrument whose importance was 
evaluated by one single question.

The importance regarding the work aspects was presented in two forms. Some studies brought paired comparisons ${ }^{(32,35,38)}$, whose technique establishes the comparative judgment, two by two, among work components.

Other researchers have chosen to use six- or sevenpoint Likert scales, whose answer choices ranged from "none or minimum importance" to "total or maximum importance"(24,26,36) and between "I totally disagree" and "I totally agree"(27,40). This format consists of several instruction headings that express one point of view of a certain topic and allows the worker to express the importance of each of the items that compose the instrument ${ }^{(32)}$. In two studies ${ }^{(27,40)}$, the analysis of the question that measures the importance in the instrument was not performed in a independent manner, rather, it was incorporated to the general result of satisfaction.

Only one study ${ }^{(36)}$ used a global question to evaluate QLW, however the workers answered to this question in a Likert Scale of 7 points.

Regarding the study populations, nurses were the most often investigated. Eleven researches addressed this category ${ }^{(24,26-32,36,38,40)}$ with exclusiveness, five ${ }^{(25,33,35,37,39)}$ included all nursing workers, and just one ${ }^{(34)}$ addressed the satisfaction of nursing technicians.

\section{DISCUSSION}

In Brazil, it has been observed there is a concern toward investigating QLW among nursing professionals, also measured as satisfaction at work. It is verified that the reality is similar to that found internationally. In other words, studies have evaluated QLW by means of general $^{(26-28,40)}$ or specific ${ }^{(35,38-39)}$ instruments, adapted instruments designed by researchers from other countries ${ }^{(32)}$, and some have built new instruments specific for nurses ${ }^{(29,36)}$.

Although the located studies were performed in the late 80 's ${ }^{(24)}$ and early 90 's ${ }^{(25)}$, the result of the present study suggests that there is still a need from more research on QLW among nursing professionals, since it is a theme of interest for workers and organizations, both. Such studies collaborate to modify the way that workers accomplish their tasks, facilitating their work and providing them with more satisfaction, and contributing to improve institution management.

The nurses were the most often investigated in the selected studies, and only a research addressed only technical nursing professionals. This aspect demonstrates that studies concerning this issue present different perspectives and they can be influenced by institutional and personal interests. However, it is understood that QLW and professional satisfaction will be obtained when all the hierarchical levels reach the same goals and the same value.

However, this aspect can bring consequences to the studies performed in Brazil, since in other countries, like the USA, the inexistent nursing categories could complicate the comparisons between the results of QLW studies of the technical-level professionals and also of the nurses in our country, since the work situations in each country are very different.

About the results obtained according to the criteria for the evaluation of the 17 studies selected, it is observed that there was no consensus about what QLW means. The several concepts related to QLW reinforce our initial perception regarding the complexity and the several lines of thought among researchers. The high occurrence of the term "professional satisfaction", as a concept for QLW, also reinforces what had already been pointed out in another study ${ }^{(39)}$, which described that professional satisfaction has been the most common form used by nurses to refer to QLW.

In this sense, some authors ${ }^{(23,42)}$, that address the quality of life theme, affirm that the confusion in the literature regarding the meaning of highly subjective terms could be reduced if the researchers defined which is concept is used in her studies.

Thesis and dissertation authors presented the concepts used in their studies, while most of the other researchers did not describe the adopted definition. We believe there still are several aspects related to QLW studies that need to be implemented so as to have a larger development of the theme in the national setting. Furthermore, this is an important characteristic to evaluate the quality of the studies on this issue, as well as the presentation of the investigated domains.

A domain or component of an evaluation instrument is what identifies the particular attention focus of the study. A domain can comprehend a single item or several related items ${ }^{(23)}$. In our analysis, we verified that more than $50 \%$ of the revised studies presented QLW domains that were being researched, and those most addressed were: payment, interaction, professional status, work requirements or goals, autonomy, politics or organizational rules and the opportunity to develop. All of these domains are cited in most of the instruments used.

There was no consensus, however, about which ones of the work components evaluate. What we observed is that the kind of measure instrument and the proposed components were influenced by the theoretical framework that grounded the research.

The instruments most often used were the Index of Professional Satisfaction (ISP) ${ }^{(32,35,38-39)}$ and the Work Satisfaction Measure Questionnaire ${ }^{(27,40)}$, which presented six and seven domains, respectively, which 
included the following: payment, professional status, and autonomy.

We also found studies that used essay and multiplechoice questions ${ }^{(25,30-31,33-34,37)}$ about the addressed issue, which has been discouraged by some authors, since there is no way to determine the precision and validity of these instrument, and it is difficult to compare the results with that of other studies ${ }^{(42)}$. The presentation of instrument validity and precision is one of the criterions that determine the quality of the study ${ }^{(42)}$.

The development of a measurement instrument implies in performing theoretical, empiric, and analytic procedures. The theoretical procedures include the stage of theory outline about the construct and dividing the construct into items, making it more operational. The empirical and analytical procedures comprise the instrument validation phase, such that the empiric procedure comprehends the data collection stages and techniques, with a view to analyzing the psychometric quality of the instrument; while the analytic procedures comprehend the statistical procedures that demonstrate that the instrument is valid and accurate ${ }^{(43)}$.

To analyze the reliability or precision, which refers to the consistency of the scores obtained by the same people when they are re-examined with the same test and in different occasions, we can adopt the following strategy: retest reliability ${ }^{(44)}$.

The validity of an instrument refers to that which the test measures and how well it does that. In other words, whether the instrument measures what it intends to measure. The validity tests used usually refer to the apparent, content, construct (factorial analysis) and criterion validity ${ }^{(44)}$.

Two analyzed instruments, ISP ${ }^{(32)}$ and the Nurse QLW Measurement Instrument ${ }^{(36)}$, was considered valid and reliable, because they present the previously stated stages. Moreover, they were considered adequate for the proposed studies and, although the instrument elaborated for Nurses QLW Measurement met all the validation criteria, the long format, with 65 items, may be limiting its use, suggesting the production of a brief version.

It was observed that only one study ${ }^{(36)}$ used a global question to evaluate QLW. For some authors ${ }^{(23,42)}$ a global question presented in the form of an essay may reflect different values and personal preferences among individuals. However, it may also determine several categories that complicate the result analysis and, thus, limit its use.

In the revised study ${ }^{(36)}$, the author used a 7 -point Likert scale to evaluate the workers' answers. This strategy facilitated the use of the global question and allowed comparisons with the instrument's total score. Other form of employing the global question was suggested in a study on quality of life, which suggests using such question with the supplied answers by means of a Visual Analogical Scale ${ }^{(42)}$, which has been quite used lately.

\section{CONCLUSION}

Only 17 of the 47 studies on QLW and professional satisfaction met the established selection criteria.

According to the seven evaluation criteria proposed, we observed that not every author defined QLW or satisfaction at work in their studies. Only eight conceptualized the term and most related the concept of QLW to professional satisfaction. There was also no consensus among components of the surveyed studies, despite 11 studies presenting the evaluated dimensions.

The components addressed most often in the 17 studies were: payment, professional status, work requirements, autonomy, organization policy and opportunity for development.

Despite having found seven distinct instruments for measuring QLW, it was verified that the using questionnaires with essay and multiple-choice questions with purposes restricted to the proposed studies is still a well-disseminated practice around the country. Only two of the surveyed instruments met the validity and precision criteria, and were considered adequate: the ISP and the Measure Instrument Nurse QLW, although all have been adjusted to meet the study goals. The most used instrument was the ISP, used in four investigations.

The importance regarding work components was addressed in only eight studies. The global question about QLW was presented in only one study.

Nurses were evaluated, predominantly, expressing the need for more studies involving the other nursing categories.

\section{FINAL CONSIDERATIONS}

Considering the obtained results and the recommendations that have been made by the researchers addressing quality of life and health-related quality of life, we suggest that the further studies clearly present what they consider as QLW. In other words, present the definition or concept used in the study. Choosing the instruments should be ruled not only by the existence of its version in the language and culture in which the study will be performed, but by the evaluation of its psychometric properties (validity and reliability) and, fundamentally, by analyzing its adequacy in answering the questions of the study to be performed. 


\section{REFERENCES}

1. Rodrigues MVC. Qualidade de vida no trabalho: evolução e análise no nível gerencial. 2a ed. Petrópolis: Vozes; 1994.

2. Chiavenato I. Introdução à teoria geral da administração. 6a ed. Rio de Janeiro: Campus; 2000.

3. Conte AL. Qualidade de vida no trabalho. Rev FAE Business. 2003; 7:32-4.

4. Lacaz FAC. Qualidade de vida no trabalho e saúde/doença. Cienc Saude Coletiva. 2000; 5(1):151-61.

5. Walton RE. Quality of Working Life: What is this? Slow Manag Rev. 1973; 15(1): 11-21.

6. Severinsson EI, Kamaker D. Clinical nursing supervision in the workplace - effects on moral stress and job satisfaction. J Nurs Manag. 1999; 7(2): 81-90.

7. Severinsson E, Hummelvoll JK. Factors influencing job satisfaction and ethical dilemmas in acute psychiatric care. Nurs Health Sci. 2001; 3(2):81-90.

8. Murrells T, Clinton M, Robinson S. Job satisfaction in nursing: validation of a new instrument for the UK. J Nurs Manag. 2005; 13(4): 296-311.

9. Cimete G, Gencalp NS, Keskin G. Quality of life and job satisfaction of nurses. J Nurs Care Qual. 2003; 18(2): 151-8.

10. Flanagan NA, Flanagan TJ. An analysis of the relationship between job satisfaction and job stress in correctional nurses. Res Nurs Health. 2002; 25(4): 282-94.

11. Kalliath T, Morris R. Job satisfaction among nurses: a predictor of burnout levels. J Nurs Adm. 2002; 32(12):64854.

12. Spector PE. Measurement of human service staff satisfaction: development of the Job Satisfaction Survey. Am J Community Psychol. 1985; 13(6):693-713.

13. Stamps P, Piedmonte E. Nurses and work satisfaction: an Index for Measurement. Ann Arbor: Health Administration Press; 1986.

14. Harris PE, Hingley P, Cooper CL. Nurse Stress Index. Yorkshire: Resource Assessment \& Development, 1988.

15. Mueller CW, McCloskey JC. Nurses' job satisfaction: a proposed measure. Nurs Res. 1990; 39(2):113-7.

16. $\mathrm{Ng} \mathrm{SH}$. A job satisfaction scale for nurses. N Z J Psychol. 1993; 22(1): 46-53.

17. Traynor M, Wade B. The development of a measure of job satisfaction for use in monitoring the morale of community nurses in four trusts. J Adv Nurs. 1993; 18(1): 127-36.

18. Centro Latino Americano e do Caribe de Informações em Ciências da Saúde. Bases de dados Bibliográficos. São Paulo: BVS; 2006.[citado 2007 Dez 11]. Disponível em: http://www.bireme.br

19. DEDALUS: Banco de Dados Bibliográficos [Internet]. São Paulo:SIB/USP; c2001. [citado 2007 Dez 11]. Disponível em: www.usp.br/sibi)

20. UNICAMP-ACERVUS : Livros e Teses [Internet]. Campinas: SBU; c1997-2006. [citado 2007 Dez 11]. Disponível em: http://www.sbu.unicamp.br/sbu/ index.php?link $=30 \mathrm{e}$

21. UNIFESP: Biblioteca Central [Internet]. São Paulos:UNIFESP; c2001. [citado 2007 Dez 11]. Disponível em: www.biblioteca.epm.br)

22. UNESP-ATHENA : Banco de Dados Bibliográficos da UNESP. São Paulo:Coordenadoria Geral de Bibliotecas; c 2001. Disponível em: http://www.unesp.br/cgb/ index_portal.php

23. Gill TM, Feinstein AR. A critical appraisal of the quality of quality-of-life measurements. JAMA. 1994; 272(8): 61926. Comment in: JAMA. 1994; $272(8): 630-1$. JAMA. 1995; 273(11):843-4; author reply 844-5. JAMA. 1995;
273(11):843; author reply 844-5. JAMA. 1995; 273(11):844; author reply 844-5. JAMA. 1995; 273(11):844; author reply 844-5.

24. Cassiani SHB, Pelá NTR, Cunha AMP, Fabri MI. A satisfação e o trabalho de enfermeiras de centro cirúrgico em Ribeirão Preto. Jornada de Enfermagem em Centro Cirúrgico do Estado de São Paulo, 1989. Anais. 1989. p. 417-32.

25. Jacomo YA. Fatores de satisfação e insatisfação que interferem na prática do pessoal de enfermagem em assistência primária de saúde: estudo realizado no município de Cotia [dissertação ]. São Paulo: Faculdade de Saúde Publica da Universidade de São Paulo; 1991.

26. Vieira DFVB. Qualidade de vida no trabalho dos enfermeiros em hospital de ensino [dissertação]. Porto Alegre: Universidade Federal do Rio Grande do Sul; 1993.

27. Del Cura MLA. Satisfação profissional do enfermeiro [dissertação]. Ribeirão Preto: Escola de Enfermagem de Ribeirão Preto da Universidade de São Paulo; 1994.

28. Sawada NO, Galvão CM. A satisfação no trabalho do enfermeiro de Centro de Material. In: $2^{\circ}$ Congresso Brasileiro de Enfermagem em Centro Cirúrgico. 1995. Anais. 1995. p. 148-50.

29. Santos SR, Rodrigues Filho J. Enfermagem: fatores de satisfação. Rev Bras Enferm. 1995; 48(3): 242-50.

30. Antunes AV, Santana LR. Satisfação e motivação no trabalho do enfermeiro. Rev Bras Enferm. 1996; 49(3): 425-34.

31. Dias TA. Fatores determinantes de satisfação nas relações de trabalho entre enfermeiros do Hospital Regional de Cascavel (HRC) [dissertação]. Ribeirão Preto: Escola de Enfermagem de Ribeirão Preto da Universidade de São Paulo; 1999.

32. Lino MM. Satisfação profissional entre enfermeiras de UTI: adaptação transcultural do Index of Work Satisfaction (IWS) [dissertação ]. São Paulo: Escola de Enfermagem da Universidade de São Paulo; 1999.

33. Venâncio CA. Qualidade de vida no trabalho X estressores freqüentes a que estão sujeitos os profissionais de enfermagem que atuam no serviço de transplante de medula óssea [dissertação]. Curitiba: Departamento de Saúde Comunitária. Setor de Ciências da Saúde. Universidade Federal do Paraná; 2000.

34. West AAA, Lisboa MAPLP. Satisfação no trabalho e perfil dos funcionários do Centro de Material e Esterilização. Rev SOBECC. 2001; 6(4):7-21.

35. Matsuda LM. Satisfação profissional da equipe de enfermagem de uma UTI-adulto: perspectivas de gestão para a qualidade da assistência [tese]. Ribeirão Preto: Escola de Enfermagem de Ribeirão Preto da Universidade de São Paulo; 2002.

36. Carandina DM. Qualidade de vida no trabalho: construção e validação de um instrumento de medida para enfermeiras [tese]. São Paulo: Escola de Enfermagem da Universidade de São Paulo; 2003.

37. Meirelles NF, Zeitoune RCG. Satisfação no trabalho e fatores de estresse da equipe de enfermagem de um centro oncológico. Esc Anna Nery Rev Enferm. 2003; 7(1):78-88.

38. Lino MM. Qualidade de vida e satisfação profissional de enfermeiras de unidades de terapia intensiva [tese]. São Paulo: Escola de Enfermagem da Universidade de São Paulo; 2004.

39. Schmidt DRC. Qualidade de vida e qualidade de vida no trabalho de profissionais de enfermagem atuantes em unidades do bloco cirúrgico [dissertação]. Ribeirão Preto: 
Escola de Enfermagem de Ribeirão Preto da Universidade de São Paulo; 2004.

40. Ferreira EM, Possari JF, Moderno AMB. Fatores de satisfação e insatisfação profissional do enfermeiro de centro cirúrgico de um hospital universitário de grande porte. Rev SOBECC. 2006; 11(2):15-23.

41. Haddad MCL. Qualidade de vida dos profissionais de enfermagem. Espaço Saúde. 2000;1(2):75-88.

42. Velanovich V. The quality of quality of life studies in general surgical journals. J Am Coll Surg. 2001; 193(3): 288-96.

43. Pasquali L. Princípios de elaboração de escalas psicológicas. Rev Psiquiatr Clin (São Paulo). 1998; 25(5): 206-13.

44. Anastasi A, Urbina S. Testagem psicológica. 7a ed. Porto Alegre: Artmed; 2000. 